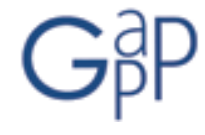

GESTIÓN Y ANÁLISIS DE POLÍTICAS PÚBLICAS, Nueva Época, n 12 julio-diciembre 2014 ISSN: 1989-8991

\title{
Principios éticos
}

Los trabajos enviados para su publicación en la revista GAPP habrán de ser obras originales de quienes figuren como autores de los mismos.

Se entenderá por plagio: la presentación de un trabajo ajeno, dándolo como propio; la inclusión de frases, conceptos o ideas de otros autores sin citar su procedencia o citándola de manera incorrecta; el empleo de citas literales o parafraseadas sin indicar la fuente; y la utilización abusiva de frases e ideas de otros autores, aún citando su procedencia.

Por otra parte, se considerará mala conducta científica: la invención de la totalidad o parte de los datos de la investigación contenidos en el original enviado para su publicación; la falsificación o manipulación de los mismos; los conflictos de autoría y la autoría ficticia.

En el supuesto de que detecte algún caso de malas prácticas o plagio, el Consejo de Redacción propondrá a la Dirección del INAP la adopción de las medidas que crea oportunas, recayendo en el autor o autores la responsabilidad jurídica o académica que corresponda por vulnerar derechos ajenos o los principios éticos aquí reflejados.

Manuscripts submitted to GAPP Journal must be original works of the authors.

Plagiarism is understood to be: any submission of a manuscript of another author as an own original work; the use of expressions, thoughts and ideas of another authors without a correct indication of their origin; the use of quotes without specification of the source; and the abusive use of expressions and thoughts of another authors, even if the source is included.

On the other hand, scientific malpractice is understood to be: the fabrication either in whole or in part of the data from a research included in the submitted manuscript; the forge o the manipulation of the data; authorship conflicts, and fictitious authorship.

The Editorial Board will propose to INAP the adoption of the appropriate measures in the case of plagiarism or scientific malpractice. The authors will be responsible either legally or scientifically of the violation of the rights of others or the principles previously enunciated. 